\title{
PENULISAN PAPAN PETUNJUK ARAH
}

NURUL INDARSIH

9173770410137

nurullindarsihh@gmail.com

1. Bentuk Kegiatan

Penulisan papan petunjuk arah

2. Lokasi

Desa bintocini kecamatan rumbia

3. Hari/Tanggal dan Waktu

Rabu, 02-10-2020. Jam 10:39

4. Peserta yang Dilibatkan

- Mahasiswa KKLP

- Pemuda karang taruna

5. Alasan Diadakannya

Agar memudahkan membaca papan petunjuk tersebut

6. Tujuan dan Manfaat

Memudahkan masyarakat dalam menemukan lokasi yang di cari.

7. Produk Kegiatan (Jika Ada)

Papan petunjuk

8. Deskripsi Kegiatan

Penulisan papan petunjuk di lakukan pada jam 10 di belakang masjid Al-ikhlas Dusun Palloli, yang di bantu oleh pemuda karang taruna desa Bontocini.

9. Referensi Wajib

- HERIANTO, H., \& Amir, A. S. (2020, September 10). Pedoman Pelaksanaan Kuliah Kerja Lapangan Plus (KKLP) Mahasiswa STIE dan STKIP YAPTI Jeneponto.

https://doi.org/10.31219/osf.io/7dvpk 